As in any ordinary checklist the principal emphasis is on nomenclature. We can get nowhere until that is straightened out. Dr. Deignan handles the matter with his usual extreme competence. But one cannot help regretting that only Latin names are used throughout. This is carrying scholarship to absurdity-especially as a large number of the birds dealt with are migrants with names commonly known to ornithologists all over the world. There is an effective numbered map and a good cross-reference system for localities in the text. The status of each species is summarised distribution-wise. Owing to the poverty of field observation, it is probably impossible to supply much information on the relative abundance or rarity of the resident species. But perhaps it was a pity not even to indicate which are the very common formsmy own Thai list based on sporadic visits over the last fifteen years, is of well over eighty species that anyone can see. More important, in the present context, no indication is given where species are rare or in any sort of difficulty, present or potential.

But it would be ungrateful to look a gift horse in the mouth. Dr. Deignan has set a foundation on the basis of which others can tackle these sorts of problem. With the population explosion of South-east Asia going hand in hand with huge new political ideas of development, land use, jungle felling, etc., etc., the need to translate scientific facts into simple intelligible ideas becomes daily more acute. With Dr. Dillon Ripley as the new secretary of the great institution which published this 265-page Checklist, we may hope for some new thinking in that direction-all the more so since Dr. Ripley himself is another of the few true naturalists of South-east Asia.

TOM HARRISSON

\title{
Man, Nature and Disease, by Richard Fiennes. Weidenfeld and Nicolson, 36s.
}

War, pestilence, and famine have been, in the past, the prime factors controlling human populations. The introduction of massive weapons of destruction has largely removed the first; modern medicine is racing ahead to remove the second, and has virtually done so in the more advanced communities ; and attempts are being made to eliminate the last remaining inhibitor of a wholesale population explosion. Such problems must worry anyone with a degree of biological understanding for, far from being an interesting scientific exercise of some economic importance, such as are many of the studies of population dynamics in other animals, this is one which affects ourselves and our children most intimately, or will do so in a few years.

Mr. Fiennes' work as a veterinary surgeon in Africa brought him into contact not only with animal disease but also with human sickness and its social problems in more natural environments than we see in Britain. More recently, as pathologist to the Zoological Society of London, he has developed the study of comparative medicine in the laboratory, so following up his earlier work in the "field". In this book he sets out some of the health problems of the more natural human populations, which education and medical science are doing so much to control. He traces the history and natural history of certain of the pestilences of mankind through from Biblical and classical times to the present day, and deals with some of the major infections such as leprosy, poliomyelitis and malaria, before passing on to the inter-relationship between human diseases and the causative organisms, bacteria, viruses, and those remarkable parasites with complicated life histories. His recent work has led him into the realms of stress sickness in animals as well as in man where, due to disorganisation of the output of 
hormones from the suprarenal or adrenal glands, quite profound and often long-standing illness can ensue. Diseases due to congenital or genetic defects and, of course, senility are also brought more sharply into view. Thus with man's conquest of certain health problems others remain still to be solved.

It would be churlish to carp at the minor details of this book for Mr. Fiennes has done what few people of his standing would care to attempt and at the same time produced a most stimulating and readable work. But one feels that sometimes the really acute problems have not been grasped sufficiently firmly so that for the general reader they appear more interesting than serious.

\section{K. M. BACKHOUSE}

\section{The Universe, by David Bergamini. The Earth, by Arthur Beiser.} Evolution, by Ruth Moore. Life Nature Library, Time-Life International, 32s. 6d. each.

David Bergamini recalls the historical steps of man's extraordinary knowledge of the universe, from the observations of the Chinese, who recorded eclipses in 4000 B.C., to the radio telescopes of to-day, which can tell us of galaxies millions of light years away, and gives a fascinating account of our own galaxy and the comets and meteorites which accompany our journey through space.

Dr. Beiser discusses three theories of the formation of continents, considers the earth's weather, hurricanes and other natural phenomena, and in the final chapter suggests that, millions of years before the world ends in some celestial disaster, man must learn to manage it better, lest he manage his own premature extinction.

Ruth Moore, one of America's foremost writers of popular science, starts historically with Thales, Aristotle, Lamarck and de Buffon, then turns to Darwin. Discussing heredity she gives clear and simple explanations for the unscientific reader of Mendel's experiments and of genes, chromosomes and the nucleic acids. In a section devoted to fossil remains of man's early relations, she should have mentioned that, though the importance of Dr. Leakey's fine work in the Olduvai gorge is universally recognised, the conclusions he draws are the subject of considerable scientific dispute.

Like previous volumes all these three are beautifully illustrated and are strongly recommended.

\section{L. BOYLE}

\section{Kiki the Mousebird, by Lyn and Hubert Gutteridge. Collins, 21 s.}

The Gutteridges have made their home on St. Lucia estuary in South Africa into a bird sanctuary where Mrs. Gutteridge nurses any injured or orphaned birds, returning them to the wild as soon as they are fit. This is the story of one that refused to go. Young birds and mammals, reared by humans, transfer to them the emotions, whatever they are-and even to the most convinced behaviourists they look like love-that they have felt for their natural parents. Nearly all lose this attitude as soon as they can fend for themselves, but there are exceptions, and Kiki is one. Although quite free, and with birds of his own species frequenting the garden, he remains firmly attached to his adopted parent, exhibiting at time a frantic jealousy of her husband and other birds.

This is a simple story, perhaps too simple for some readers, but this kind of experience has an age-old appeal. One of the remarkable things is the response of the Zulus to Mrs Gutteridge's activities. Kiki came to her through 